\title{
Quantitative assessment of the variability in chemical profiles from source apportionment analysis of PM10 and PM2.5 at different sites within a large metropolitan area
}

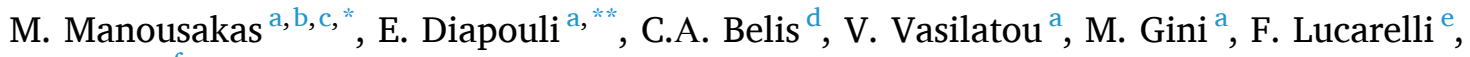 \\ X. Querol ${ }^{\mathrm{f}}$, K. Eleftheriadis ${ }^{\mathrm{a}}$ \\ ${ }^{a}$ E.R.L., Institute of Nuclear \& Radiological Sciences \& Technology, Energy \& Safety, N.C.S.R. Demokritos, 15310, Ag. Paraskevi, Attiki, Greece \\ b Institute of Nuclear and Particle Physics, NCSR "Demokritos", 15310, Ag. Paraskevi, Greece \\ ${ }^{\mathrm{c}}$ Laboratory of Atmospheric Chemistry, Paul Scherrer Institute (PSI), 5232, Villigen, Switzerland \\ ${ }^{\mathrm{d}}$ European Commission, Joint Research Centre, via Fermi, 2748 21027, Ispra, Italy \\ ${ }^{\mathrm{e}}$ National, Institute of Nuclear Physics (INFN) - Florence Section, Sesto F.no (Fi), Italy \\ ${ }^{\mathrm{f}}$ Institute of Environmental Assessment and Water Research (IDAEA-CSIC), 08034, Barcelona, Spain
}

\section{A B S T R A C T}

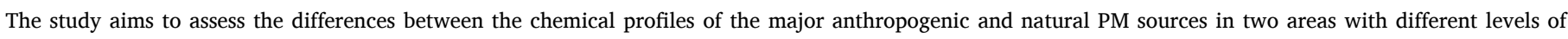

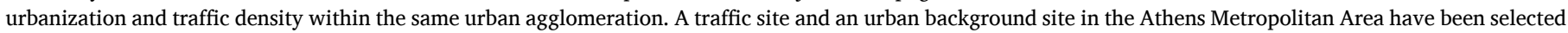

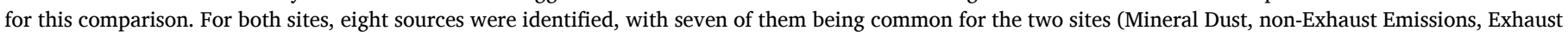

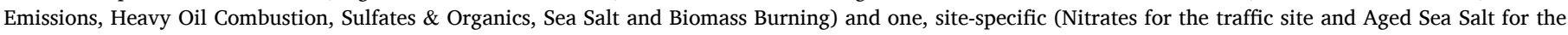

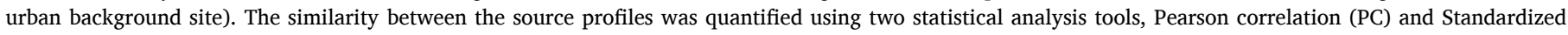

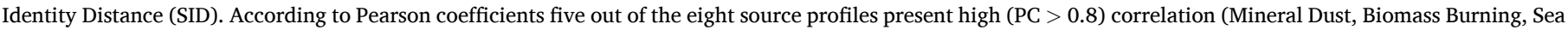

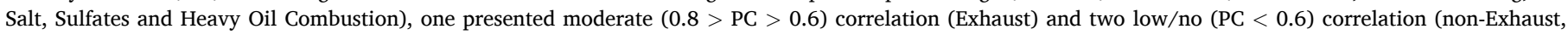

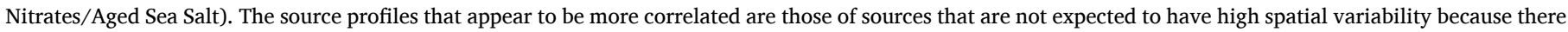

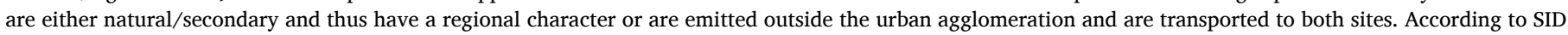

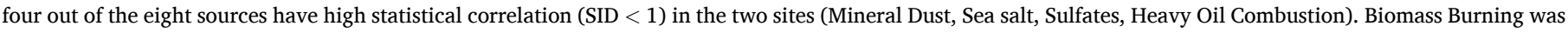

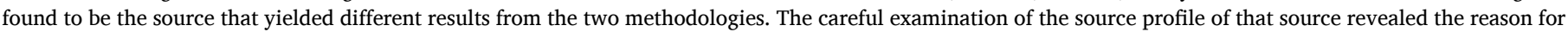

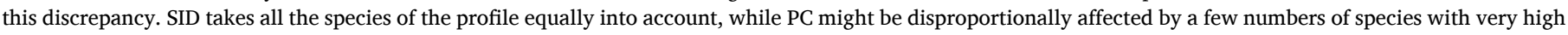

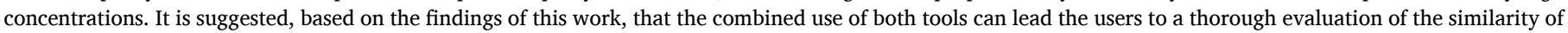

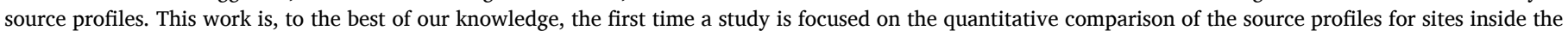
same urban agglomeration using statistical indicators.

\section{Introduction}

The attention that is given from the scientific community and the governments on air quality remains very high. Special emphasis is given on particulate pollution since it is well established that exposure to particulate matter (PM) has adverse effects on human health (Katsouyanni, 2003; Ostro et al., 2014). The experiences gained during the last decades of air quality monitoring and management have made it very clear that particulate pollution is not easily mitigated and, for control measures to be effective, it is imperative to identify the major PM sources and target specifically on the reduction of the emissions from these sources that contribute the most in a given area. The process of identifying PM sources is known as source apportionment (Belis et al., 2014). Positive Matrix Factorization (PMF) is a widely used source apportionment tool based on receptor modeling (Hopke, 2016). PMF is very reliable, as documented by European intercomparison exercises (Belis et al., 2015a,b, 2020), and has been used in a very large number of studies around the world (Diapouli et al., 2017b, 2017a; Gunchin et al., 2019; Kim et al., 2003; Pateraki et al., 2019; Waked et al., 2014).

The numerous source apportionment studies have indicated that the

\footnotetext{
* Corresponding author. E.R.L., Institute of Nuclear \& Radiological Sciences \& Technology, Energy \& Safety, N.C.S.R. Demokritos, 15310, Ag. Paraskevi, Attiki, Greece.

$* *$ Corresponding author.

E-mail addresses: manosman@ipta.demokritos.gr (M. Manousakas), ldiapouli@ipta.demokritos.gr (E. Diapouli).
} 
contribution of sources can vary significantly even between locations that are not so far apart (Cesari et al., 2016a,b; Lee et al., 2008; Pandolfi et al., 2011). Even though there are several studies that focus on the differences between PM sources and their contributions on different areas (Cesari et al., 2016a,b), there are not many studies that focus on the differences between the chemical profiles of the sources. The type of sources that contribute in areas of similar characteristics are in most cases very similar, with sources such as traffic, biomass burning, road dust and others being almost universally present (Belis et al., 2013).

Most source apportionment studies take place on urban areas, because PM concentration levels and the population density are much higher in comparison to other areas, meaning that the number of people that are exposed to PM pollution is very high. Even though there is a classification for the atmospheric PM concentration levels in terms of measurement sites, such as suburban/urban background or traffic/kerb site, aerosol chemical composition data are often not available in every type of site to conduct separate source apportionment studies. While in source apportionment studies big cities are often treated as one environment, this assumption does not take into account that the chemical composition and concentration of PM originating from a given source may be different at the various areas of the city (Kim Oanh et al., 2009). The factors that alter most the profiles are a) some chemical reactions (acid-base; oxidation) and physical processes (e.g. photo degradation, partitioning) that act on specific components and not on others; and b) the different mix of single sources that constitute one "source category". In addition, chemical profiles may vary over time at the same location (e.g. winter summer). Particles and gaseous precursors originating from a source may undergo chemical and physical changes in the atmosphere generally described as aerosol aging (Shiraiwa et al., 2011) (production of secondary aerosol, change in particles size distribution, volatilization/condensation processes, etc.); thus, if a receptor site is at some distance from the emission source, the chemical fingerprint of the source found at the receptor site may differ significantly from the fresh source fingerprint. All the aforementioned factors affect the chemical composition of the source profiles at receptors of different characteristics regarding aerosol mixing and aging. Even though it is not possible to trace back those processes from examining the source profiles it is important to statistically asses the differences and provide meaningful understanding on the impact on the identified sources across different receptors within an extended urban area. Since the effects PM has on human health are linked not only to their mass but also to their composition and size distribution (Donaldson et al., 1997; Zwozdziak et al., 2017), the differences in the chemical fingerprints of PM sources across the various city areas may be also relevant for population risk assessment.

Source apportionment techniques based on receptor modeling use pre-selected and/or estimated by the model chemical profiles for the different PM sources. The chemical mass balance (CMB) models, for instance, use pre-selected source profiles, measured at the source or theoretically constructed (Argyropoulos et al., 2012). PMF, on the other hand, is usually applied with no prior knowledge of the source profiles (Viana et al., 2008), thus providing more flexibility in terms of identifying chemical profiles representative of the receptor sites. Nonetheless, due to limitations in data availability, some PMF studies use combined datasets of PM chemical composition from different areas within the same city, in order to produce a final dataset of substantial size to be used for source apportionment (Sarigiannis et al., 2017). This may lead to mixed profiles that are less specific for the single receptor while are more representative of the entire city.

The current study, conducted in the framework of the AIRUSE LIFE + project (ENV/ES/584), aims to assess the differences between the chemical profiles of the major anthropogenic and natural PM sources, in two areas with different levels of urbanization and traffic density within the same urban agglomeration. The results also provide insight into the uncertainty introduced when (i) average source profiles are produced by PMF, corresponding to more than one site or (ii) chemical profiles measured at the source are used to estimate source contributions at a receptor site away from direct emissions. A traffic site and an urban background site in the Athens Metropolitan Area (AMA) have been selected for this comparison. The similarity between the source profiles was quantified using two statistical analysis tools, Pearson correlation and Standardized Identity Distance. The proposed methodology, is capable only of an unbiased quantification of the differences of the source profiles produced by source apportionment methods, but cannot provide information for the processes that lead to the observed differences.

\section{Methodology}

\subsection{PM sampling and chemical analysis}

In the framework of the AIRUSE LIFE + project, $24 \mathrm{~h} \mathrm{PM} 10$ and $\mathrm{PM}_{2.5}$ samples were collected in two sites inside the AMA. The Urban Background (UB) site was at the Global Atmosphere Watch (GAW) Demokritos station (DEM -Athens), while the Traffic (TR) site was located in the city center, next to a busy street (Fig. 1).

The DEM- Athens urban background station is located inside the NCSR Demokritos campus ( $37{ }^{\circ} 99^{\prime} 50^{\prime \prime} \mathrm{N}, 23^{\circ} 81^{\prime} 60^{\prime \prime} \mathrm{E}$ ), at the northeastern corner of the Greater Athens Metropolitan Area and at an altitude of $270 \mathrm{~m}$ a.s.l. The station is away from direct emission sources in a vegetated area (pine). PM10 and PM2.5 samples were collected on Teflon filters by means of low-volume $\left(2.3 \mathrm{~m}^{3} / \mathrm{h}\right.$ ) samplers (Sequential 47/50-CD with Peltier cooler, Sven Leckel GmbH, a Tecora Echo PM sampler and a Demokritos EN12341 sampler). PM10 and PM2.5 samples were also collected on quartz microfiber filters by means of high-volume samplers (Sequential High- Volume Sampler CAV-A/MSb, MCV, SA).

The Aristotelous Monitoring station of the National Air Quality Network was selected as a typical traffic impacted site. The station is located in the Athens commercial center, at the 1st floor open balcony of the Ministry of Health, facing a busy crossroad $\left(37.99^{\circ} \mathrm{N} 23.72^{\circ} \mathrm{E}\right.$, at an altitude of $64 \mathrm{~m}$ a.s.l., Fig. 1). $\mathrm{PM}_{10}$ and $\mathrm{PM}_{2.5}$ samples were collected on Teflon filters (Pall, Teflon and Whatman, PTFE) by means of low volume $\left(2.3 \mathrm{~m}^{3} / \mathrm{h}\right.$ ) samplers (2 Sequential 47/50-CD, Sven Leckel GmbH). $\mathrm{PM}_{10}$ was also collected on quartz microfiber filters (Pall Tissuequartz) by means of low Volume Samplers (Sequential Low-Volume Sampler, MCZ, GmbH or Derenda PNS 16-3.1). After the end of the TR site campaign, parallel sampling of $\mathrm{PM}_{2.5}$ and $\mathrm{PM}_{10}$ on quartz filters was performed during a 2-week period, by means of low volume $\left(2.3 \mathrm{~m}^{3} / \mathrm{h}\right)$ samplers $(2$ Sequential 47/50-CD, Sven Leckel GmbH). These samples were used for elemental (EC) and organic carbon (OC) analysis, in order to derive an indicative PM2.5/PM10 ratio for these two species at the TR site.

The sampling campaign in the traffic station (TR) was performed during the summer of 2013 (July and August) and the winter of 2014 (January and February). The total number of collected samples was 140 $\left(68 \mathrm{PM}_{2.5}\right.$ and $72 \mathrm{PM}_{10}$ ). The sampling campaign in the urban background station lasted for 12 months (February 2013 to February 2014) and the total number of collected samples in this case was 439 (235 $\mathrm{PM}_{2.5}$ and $204 \mathrm{PM}_{10}$ ).

The $\mathrm{PM}_{2.5}$ and $\mathrm{PM}_{10}$ mass concentrations were determined gravimetrically from the Teflon filters, following the standard operating procedure EN1234. The Teflon filters were also analysed by Particle Induced X-Ray Emission (PIXE) (Lucarelli et al., 2014) for major and trace elements (S, Mg, Al, $\mathrm{Si}, \mathrm{Ca}, \mathrm{Fe}, \mathrm{Cu}, \mathrm{Zn}, \mathrm{Ba}, \mathrm{Ni}, \mathrm{V}, \mathrm{Cr}, \mathrm{Pb}, \mathrm{As}, \mathrm{Ti}, \mathrm{Mn}$, $\mathrm{Ba}, \mathrm{Pb}, \mathrm{Cd}, \mathrm{Sb})$ and for ionic species by Ion Chromatography (IC) $\left(\mathrm{SO}_{4}^{2-}\right.$, $\mathrm{NO}_{3-}, \mathrm{NH}_{4}^{+}, \mathrm{K}^{+}, \mathrm{Na}^{+}$) (Amato et al., 2016). Inductively Coupled Plasma Mass Spectrometry (ICP-MS) and Inductively Coupled Plasma Atomic Emission Spectroscopy (ICP-AES) (Querol et al., 2001) (V, As, Sr, Cd, Sb) was performed on the UB quartz filters, as a complementary elemental analysis technique. All quartz filters were analysed by thermo-optical transmittance (TOT) method (EUSAAR2 protocol) for the determination of OC and EC concentrations in $\mathrm{PM}_{10}$ and $\mathrm{PM}_{2.5}$. The accuracy of PIXE elemental concentrations is determined by a sum of independent 


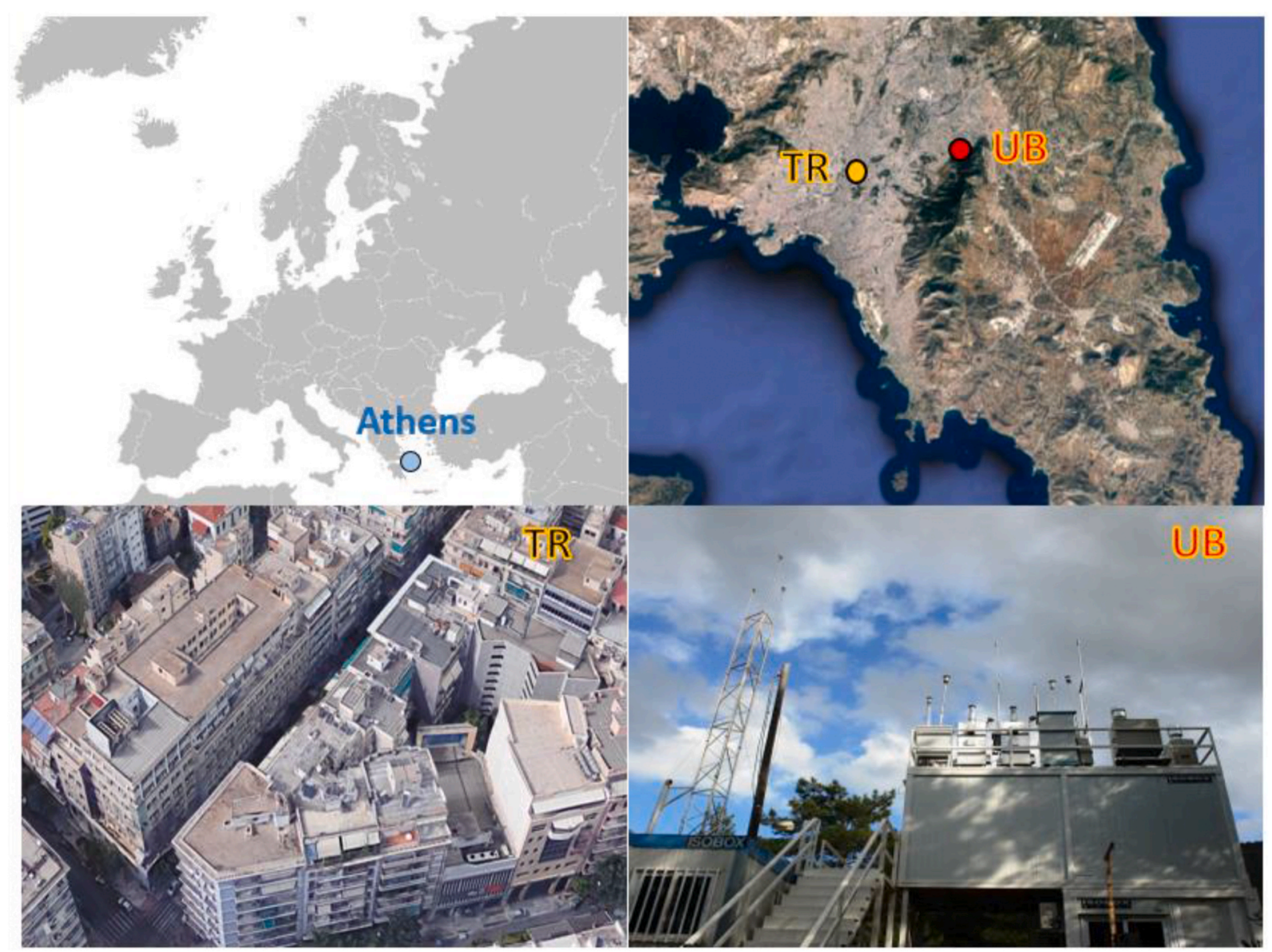

Fig. 1. Traffic (left) and urban background (right) stations in Athens metropolitan area.

uncertainties on standard samples thickness (5\%) and X-rays counting statistics (from $2 \%$ to $20 \%$ or higher when values approach detection limits); the uncertainties on concentrations measured by the other used analytical techniques are: 5-10\% for EC-OC, 5\% for ions, 5-20\% for ICP elements (Lucarelli et al., 2015). Minimum detection limits (MDLs) are in average $10-20 \mathrm{ng} \mathrm{m}^{-3}$ for $\mathrm{Na}, 5-10 \mathrm{ng} \mathrm{m}^{-3}$ for $\mathrm{Mg}, \mathrm{Al}, \mathrm{Si}, \mathrm{K}, \mathrm{Ca}$, and $1-3 \mathrm{ng} \mathrm{m}^{-3}$ for Mn, Fe, Sr (Nava et al., 2012). Details on the analytical techniques used and their corresponding uncertainties are provided in Amato et al. (2016).

\subsection{Source apportionment by PMF}

PMF analysis was performed on all samples, separately for each site, by the use of the EPA PMF 5.0 model (Norris and Brown, 2014). In both cases, the $\mathrm{PM}_{2.5}$ and $\mathrm{PM}_{10}$ data were used as a composite dataset. PMF decomposes the matrix $\mathrm{X}$, which contains the measured chemical composition data, into two matrices: the matrix $\mathrm{F}$ which corresponds to the source profiles and describes the chemical composition of the fingerprint of the sources, and the matrix $G$ which corresponds to the source contribution and contains the contribution of the sources. PMF seeks to reconstruct the matrix $\mathrm{X}$, based on the following equation:

$X=G \times F+E$

where $\mathrm{X}$ is the chemical composition matrix, $\mathrm{G}$ is the source contributions, $\mathrm{F}$ the factor profiles and $\mathrm{E}$ the residual.

PMF is a statistical model that is based on the well justified assumption that chemical species which originate from the same source are highly correlated. A problem that may arise is that correlations between the species may originate from reasons other than same origin/ source. Additionally, a source may have a different chemical fingerprint in different areas. For example, traffic chemical profile will be different if the vehicle fleet in a certain location is composed mainly of diesel vehicles or of gas vehicles. In this work, source profiles and contributions obtained from the PMF analysis for the two sites were compared, in order to obtain information regarding the similarities and dissimilarities in the impact observed at the two different sites, from the same type of sources and processes and to identify the differences that do not represent physical phenomena (or geographical variability) but statistical inaccuracies. The comparison was performed only for the common days of measurement, in order for the source contributions to be directly comparable.

The difficulty in this attempt is the quantification of the "difference" between both source contributions and especially their source profiles. In their published work, Belis et al. (2015a,b) proposed a methodology to assess source apportionment model performance and applied it in the framework of two intercomparison exercises. In the current study two metrics that are proposed in the aforementioned study are used and are namely Pearson Correlation (PC) and the Standardized Identity Distance (SID). Both methods examine the correlation between groups of variables, in this case factor profiles and contributions. The difference between them is that PC indicates how well the relationship between two variables can be described with a line, no matter what the slope and intercept are, while SID tests only the linear model with slope 1 and intercept 0 (Belis et al., 2015a,b).

The SID is defined as the ratio of the identity distance (ID) to the maximum accepted distance (MAD) (Pernigotti et al., 2016):

$S I D=\frac{1}{m} \sum_{j} \frac{\frac{1}{\sqrt{2}}\left|x_{j}-y_{j}\right|}{k \frac{1}{2}\left|x_{j}+y_{j}\right|}$ 
where $\mathrm{j}$ is the index of the $\mathrm{m}$ species in the two source profiles, and $\mathrm{x}_{\mathrm{j}}$ and $y_{j}$ are their relative masses. The ID measures how different is the abundance of every single chemical species $j$ in the two compared profiles while the MAD sets the limit, in relative terms, for the ID to be accepted. When the average ID is smaller or equal to MAD the SID is $\geq 1$ indicating that the two profiles are comparable. The coefficient $k$ accounts for the variability of the source; by default, it is set to 1 when no information about this is available. The SID is computed only for the species $j$ that are present in both profiles.

As another metric of similarity between the profiles and to indicate the robustness of PMF solutions, the DeltaSA tool that it is available online (https://source-apportionment.jrc.ec.europa.eu/) free of charge by JRC was used (Pernigotti et al., 2016; Pernigotti and Belis, 2018). Delta SA Compares the chemical profile of a factor chemical profile with the chemical profiles in SPECIATE (US-EPA) and SPECIEUROPE (EC-JRC) repositories. The similarity is computed using the Standardized Identity Distance and the Pearson Distance (PD, 1-pearson correlation coefficient). The criteria that indicate high similarity for the two methodologies are SID $<1$ and PC $>0.6$.

\subsection{Source apportionment approach and evaluation}

As discussed in the previous section, PMF analysis was performed on all samples, separately for each site, by the use of the EPA PMF 5.0 model. In both cases, the $\mathrm{PM}_{2.5}$ and $\mathrm{PM}_{10}$ data were used as a composite dataset. This methodology is not new and it was already proven to increase considerably the statistical significance of the analysis, although it assumes that the chemical profiles of sources are the same in the $\mathrm{PM}_{2.5}$ and $\mathrm{PM}_{10}$ fractions (Amato et al., 2009, 2016). The solution was thoroughly evaluated to make sure that the overall and rotational ambiguity uncertainties were low. The number of factors was decided after the investigation of a range of possible solutions starting from 4 factors up to 10. Eight factors were found to be the optimal solution (highest number of factors with physical meaning) for both sites. Strong, weak and bad variables were selected according to their $\mathrm{S} / \mathrm{N}$ (signal to noise ratio) as described in the EPA PMF 5.0 manual. The variables that were set weak were V, As, Sr, Cd and Sb. The differences between $\mathrm{Q}_{\text {true }}$ and $\mathrm{Q}_{\text {rob }}$ and also between $Q_{\text {true }}$ and $Q_{\text {the }}$ were less than $5 \%$. One hundred simulations were performed and the differences in scaled residuals between the different simulations were very low. The results of the diagnostic tools offered by EPA PMF revealed that the solution was robust with low rotational ambiguity. Bootstrap results indicated that the factors were reproduced at a minimum level of $85 \%$ of the produced resamples, while displacement and bootstrap-displacement showed no factor swaps for the minimum dQ level. The PM mass reconstruction was satisfactory. The $\mathrm{R}^{2}$ between modeled and real PM mass was over 0.87 .

Even though all collected data was used to perform source apportionment analysis, only the common dates were used for comparison of the source contributions between the different sites. Since the average source contribution at a certain receptor is not affected only by the distance from the source but from the emissions intensity of the sources in a certain time period, a comparison of source contributions for common dates for the two sites is considered more representative. On the other hand, source profiles should not vary regardless of small differences in the time periods that are covered, since they are not related with emissions intensities that vary overtime, but with the chemical composition of the source emissions which should remain stable if the source is the same. A fundamental assumption that needs to be met for receptor models to be used, is that source profiles do not vary significant overtime (Belis et al., 2014). To test the assumption that profiles are not affected in this case by the number of samples that are used, PMF analysis was performed for the UB site using as input only the common data with TR site. The factors in both cases were extremely similar (PC over 0.9 for every case). The source profiles that correspond to the runs performed with all the collected data were chosen to be used in the current study, in order to increase the statistical significance of the analysis.

\section{Results}

\subsection{PM speciation}

In Table 1 , the average mass concentrations of $\mathrm{PM}_{2.5}$ and $\mathrm{PM}_{10}$ as well as the concentrations of various major and trace elements/species are presented.

As it is presented in Table 1, most constituents have higher concentrations in TR site. The components that are related to anthropogenic emissions, especially road traffic, such as $\mathrm{NO}_{3^{-}}, \mathrm{Fe}, \mathrm{Cu}, \mathrm{Zn}, \mathrm{Ba}, \mathrm{Mn}, \mathrm{Cr}$, $\mathrm{Pb}$ and EC, OC have much higher concentrations at the TR site. Elements that are mainly associated with natural sources and specifically with soil resuspension ( $\mathrm{Al}, \mathrm{Si}, \mathrm{Ti}$ ), have higher concentrations in $\mathrm{UB}$ site. The elements that are associated with heavy oil combustion $\mathrm{Ni}$ and $\mathrm{V}$, have similar concentrations at both sites, as they are transported from industrial or/and port sites. $\mathrm{Na}^{+}$and $\mathrm{Mg}$ present comparable concentration in both sites, while $\mathrm{Cl}^{-}$has much lower concentration in UB site, even though all of them mainly originate from sea spray. The reason for that observation might be that since UB site is located further away from the sea, which is expected to be the main source of $\mathrm{Cl}^{-}, \mathrm{Cl}$ depletion may take place, leading to much lower concentrations of $\mathrm{Cl}^{-}$in the UB site. $\mathrm{K}^{+}$has higher concentration in the TR site. Finally, $\mathrm{SO}_{4}^{2-}$ and $\mathrm{S}$, which is a secondary aerosol species associated with anthropogenic emissions $\left(\mathrm{SO}_{2}\right)$ but formed rather slowly and thus mostly related to regionally transported pollution, displays similar concentrations at the two sites.

\subsection{Source chemical profiles}

For both sites the optimum PMF solution was obtained for 8 factors. The identification of sources resulted in 7 common sources for the two sites (Mineral Dust, non-Exhaust Emissions, Exhaust Emissions, Heavy Oil Combustion, Sulfates \& Organics, Sea Salt and Biomass Burning) and one site specific source (Nitrates for the traffic site and Aged Sea Salt for the urban background site). In Fig. 2 the obtained source profiles for the

Table 1

Mean PM and component concentrations for the study period at the two study sites (in $\mathrm{ng} / \mathrm{m}^{3}$ ).

\begin{tabular}{|c|c|c|c|c|}
\hline & UB PM10 & TR PM10 & UB PM2.5 & TR PM2.5 \\
\hline PM & 19,872 & 33,467 & 11,003 & 19,499 \\
\hline EC & 416 & 3348 & 324 & 2628 \\
\hline OC & 3268 & 8480 & 2724 & 6197 \\
\hline $\mathrm{SO}_{4}^{2-}$ & 3651 & 3672 & 2888 & 3346 \\
\hline $\mathrm{NO}_{3-}$ & 1164 & 2122 & 173 & 898 \\
\hline $\mathrm{NH}_{4}^{+}$ & 1013 & 1050 & 943 & 1034 \\
\hline $\mathbf{K}^{+}$ & 251 & 363 & 115 & 179 \\
\hline S & 1255 & 1281 & 911 & 934 \\
\hline $\mathrm{Cl}^{-}$ & 617 & 990 & 41 & 99 \\
\hline $\mathrm{Na}^{+}$ & 670 & 766 & 112 & 129 \\
\hline Mg & 210 & 216 & 35 & 32 \\
\hline $\mathrm{Al}$ & 400 & 288 & 90 & 56 \\
\hline $\mathrm{Si}$ & 994 & 779 & 234 & 167 \\
\hline $\mathrm{Ca}$ & 778 & 1804 & 175 & 375 \\
\hline $\mathrm{Fe}$ & 419 & 1019 & 112 & 216 \\
\hline $\mathbf{C u}$ & 6.2 & 32 & 2.2 & 6.9 \\
\hline Zn & 18 & 40 & 9.9 & 19 \\
\hline $\mathbf{B a}$ & 16.1 & 45 & 6.9 & 9.7 \\
\hline $\mathrm{Ni}$ & 2.6 & 3.4 & 1.5 & 1.6 \\
\hline V & 4 & 5.3 & 2.7 & 2.7 \\
\hline $\mathrm{Cr}$ & 2.5 & 7.6 & 2 & 3.2 \\
\hline $\mathbf{P b}$ & 4.2 & 6.1 & 2.7 & 3.7 \\
\hline As & 0.6 & 0.8 & 0.4 & 0.5 \\
\hline $\mathrm{Ti}$ & 24.7 & 23.4 & 8.2 & 7.6 \\
\hline Mn & 7.1 & 12.7 & 2.2 & 3.2 \\
\hline $\mathbf{B a}$ & BDL & 50 & BDL & 10 \\
\hline $\mathrm{Pb}$ & BDL & 6 & BDL & 4 \\
\hline Cd & 0.1 & BDL & 0.1 & BDL \\
\hline Sb & 1 & BDL & 0.5 & BDL \\
\hline
\end{tabular}


Non Exhaust

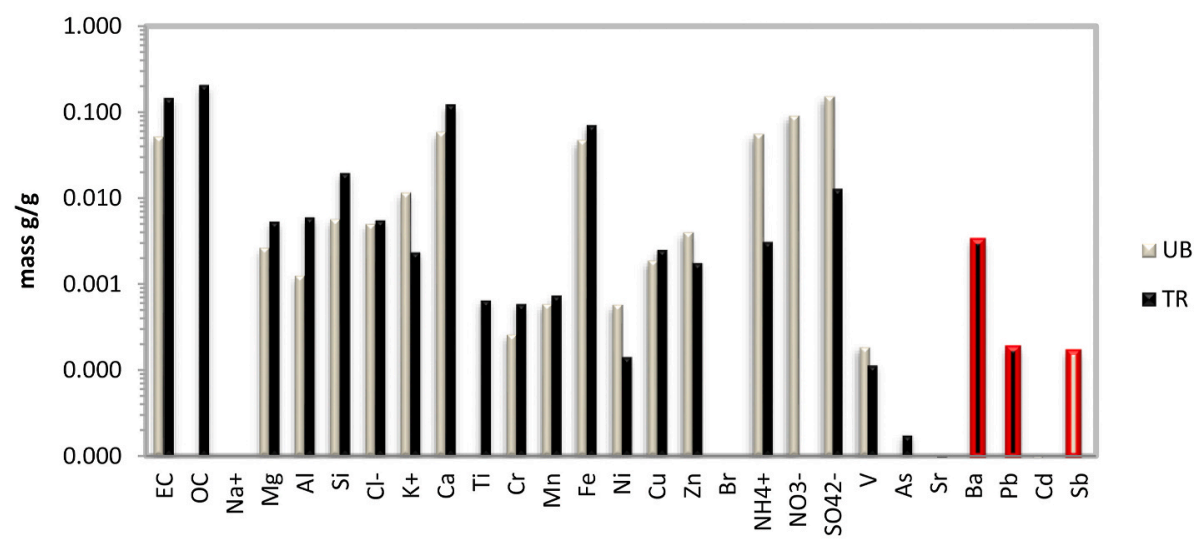

Mineral Dust

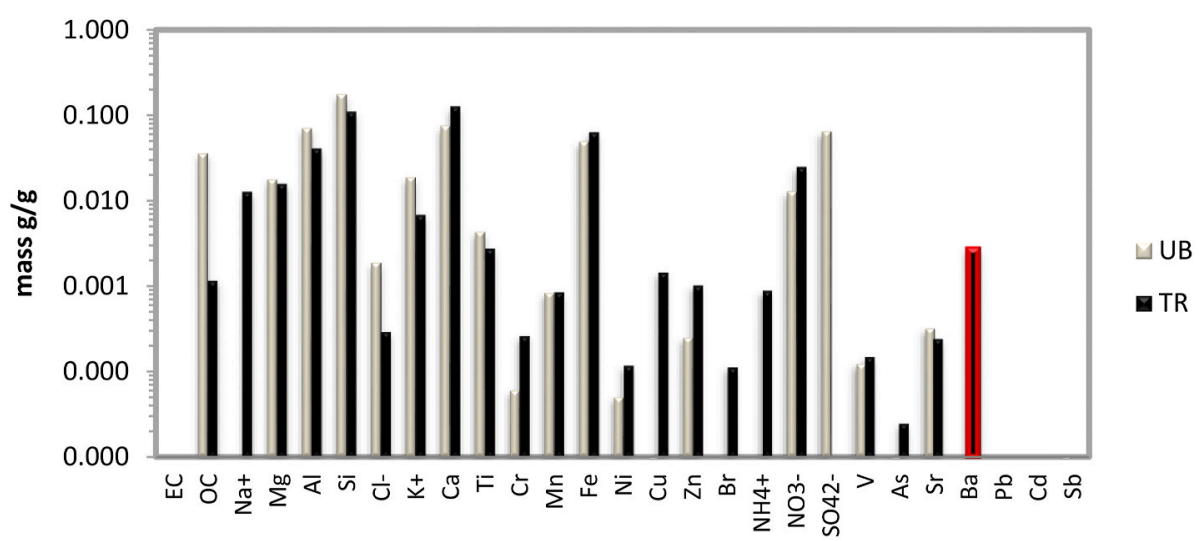

Vehicle Exhaust

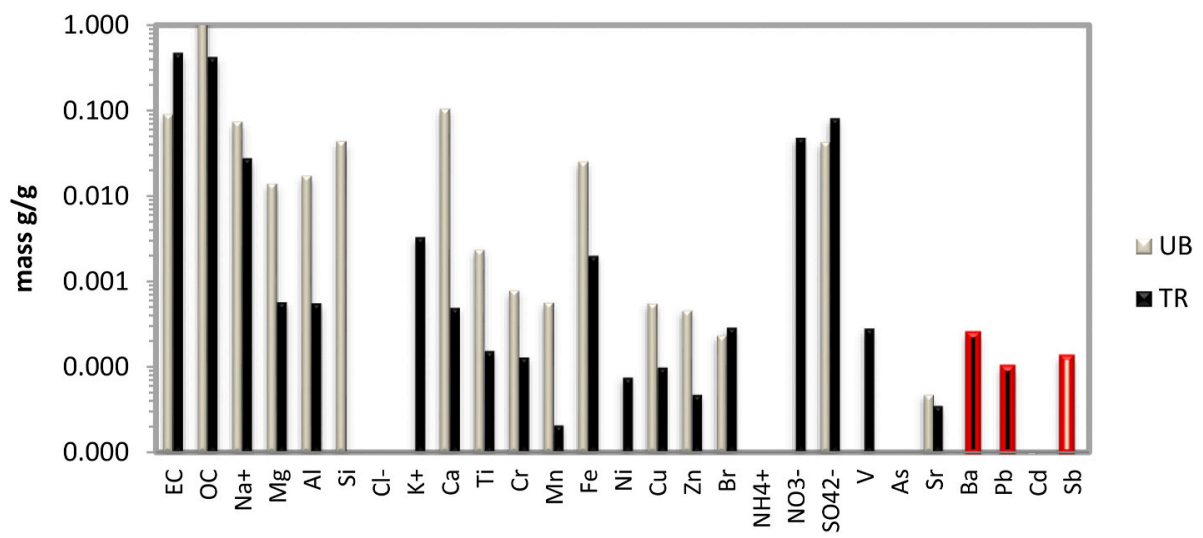

Fig. 2. Source profiles obtained by PMF for UB (blue bars) and TR sites (black bars). If the legend contains two names, the one on the right corresponds to UB and on the left to TR. Highlighted red bars correspond to $\mathrm{Cd}$ and $\mathrm{Sb}$ that were used only at the $\mathrm{UB}$ and $\mathrm{Ba}$ and $\mathrm{Pb}$ that were used only at the TR site. (For interpretation of the references to colour in this figure legend, the reader is referred to the Web version of this article.)

two sites are presented, while the relative contributions of the sources are presented in Fig. 3.

The species and elements that have been used in the two sites are identical except for $\mathrm{Cd}$ and $\mathrm{Sb}$ that were used only at the UB site and $\mathrm{Ba}$ and $\mathrm{Pb}$ that were used only at the TR site, since it was not possible to be quantified in concentrations higher than the detection limit in both areas. The presence of those elements in quantifiable concentrations in specific sites, indicates that the sources have slightly different tracers in the two occasions. For that reason, it was selected to keep the tracers in the analysis. Having that said, since those tracers have very low concentrations and relatively high uncertainties, it is not expected that they affect the shape of the factors in respect to the rest of the tracers.

The common sources at the two sites appear to have similar chemical profiles (Fig. 2). The challenge, though, is to provide a quantification of this "similarity" of the source profiles. In the current study two methods were used, which were namely Pearson Correlation and SID (Standardized Identity Distance). In Table 2 the Pearson Correlation and the Standarized Indentity Distance between the source profiles are 

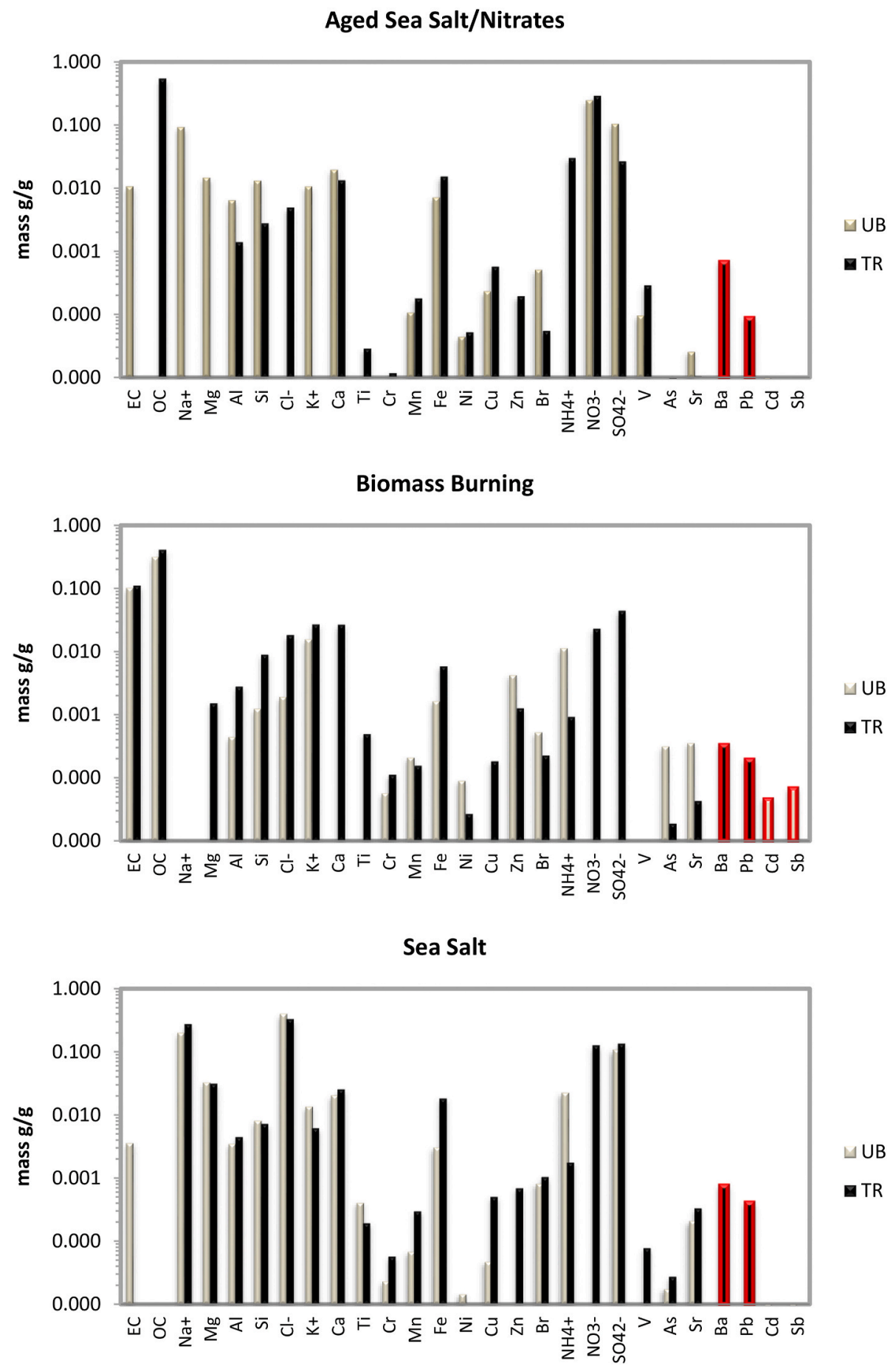

Fig. 2. (continued).

presented.

According to Pearson Correlation coefficients (Table 2) five out of the eight source profiles display high correlation $(>0.8)$ and are namely Mineral Dust, Biomass Burning, Sea Salt, Sulfates and Heavy Oil Combustion. The fact that these profiles are so similar even though the runs are different for each site is an indication of the robustness of the model. Those sources are present in many different areas around the world and present similar chemical profiles (Calzolai et al., 2015; Diapouli et al., 2016; Manousakas et al., 2017, 2015), even though sources such as re-suspended dust are pretty much dependent on the local geological substrate. Natural sources are expected to have similar profiles regardless of the site inside an urban area as the emitted chemical species are not affected by the intensity of anthropogenic activities inside the urban agglomeration. The similarity of Sulphate and Heavy Oil combustion profiles on the other hand, which are typical anthropogenic sources, may indicate a regional origin for these sources. The regional character of Sulphate in Athens has been also pointed out in previous works, based on the homogeneity of $\mathrm{SO}_{4-}{ }^{2}$ concentration levels across the greater Athens area (Diapouli et al., 2016; Theodosi et al., 2011). Similarly, Heavy Oil combustion in Athens is taking place outside the city, either in industrial areas at the west part of the peninsula or due to shipping emissions; it is, thus, in either case transported to the two sites, rather than displaying emission sources inside the Athens urban area. Finally, Biomass Burning has a very distinct source signature with respect to its 
Sulfates and Organics

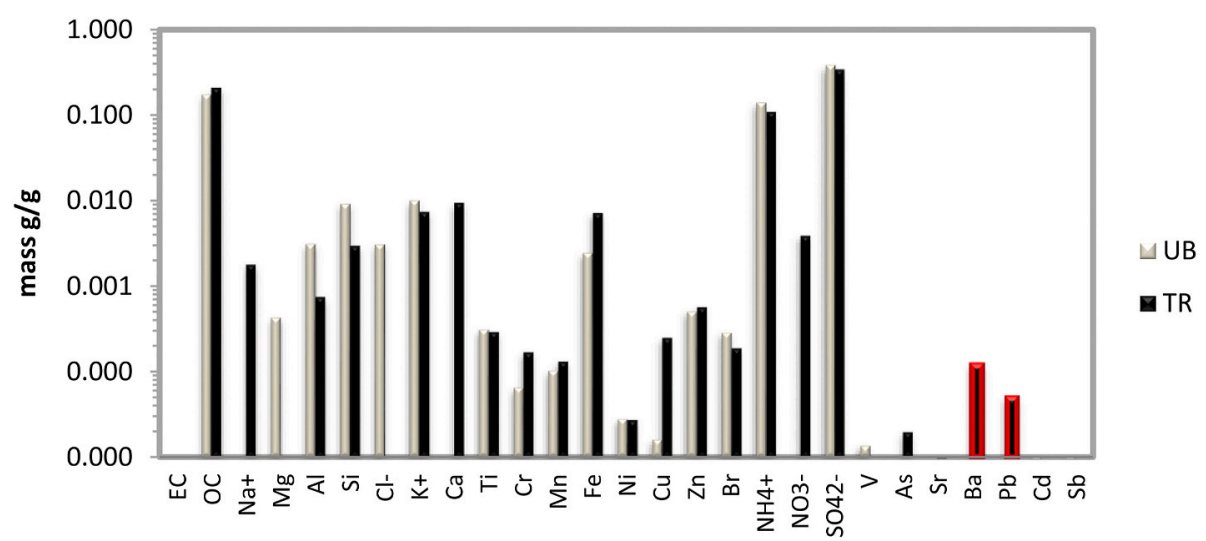

Heavy Oil Combustion

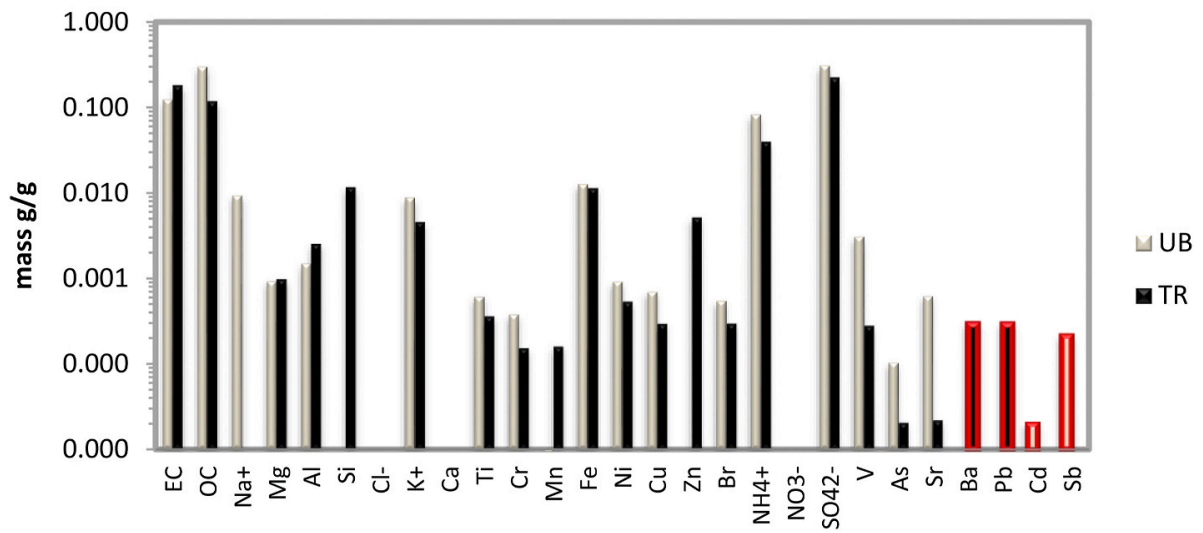

Fig. 2. (continued).

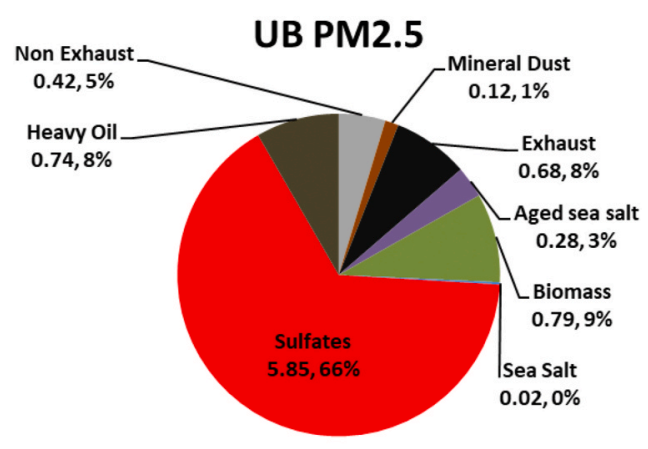

UB PM10

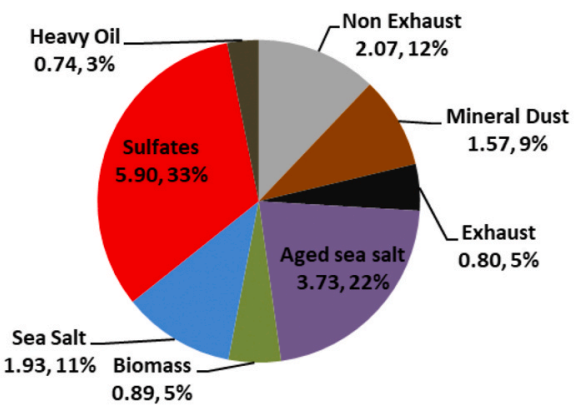

TR PM2.5

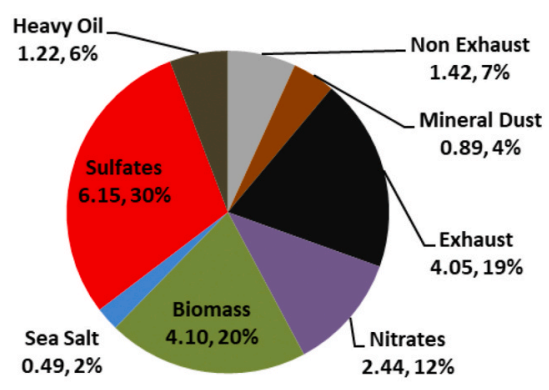

TR PM10

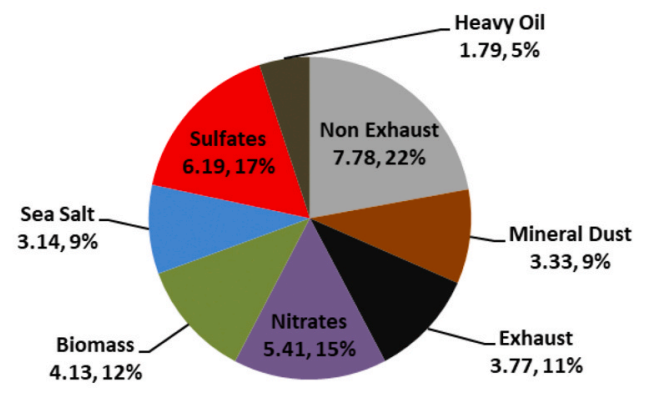

Fig. 3. Absolute $\left(\mu \mathrm{g} / \mathrm{m}^{3}\right)$ and relative (\%) average source contributions (for the common sampling dates) to the two PM fractions. 
Table 2

Pearson Correlation coefficients and SID for the source profiles of the two sites.

\begin{tabular}{|c|c|c|c|c|c|c|c|c|}
\hline & Non Exhaust & Mineral Dust & Vehicle exhaust & Nitrates/Aged sea salt & Biomass burning & Sea Salt & Sulfates and organics & Heavy Oil combustion \\
\hline PC & 0.16 & 0.81 & 0.67 & 0.35 & 0.99 & 0.93 & 0.99 & 0.89 \\
\hline SID & 1.05 & 0.96 & 1.32 & 1.41 & 1.21 & 0.92 & 0.98 & 0.86 \\
\hline
\end{tabular}

key tracers (OC and EC and the OC/EC ratio), regardless of the particular location inside the GAA (Kalogridis et al., 2017). The detailed comparison of the profiles reveals that, for Mineral Dust the contribution of the soil related elements is higher in the UB factor. This might be attributed to the fact that the surrounding area of the UB site is not paved which favors soil resuspension. The Sea Salt chemical profiles have almost identical normalized contribution of the major tracer elements $\left(\mathrm{Na}^{+}\right.$, $\mathrm{Mg}^{+2}, \mathrm{Cl}^{-}$). The main difference between the two profiles is the presence of $\mathrm{EC}$ in $\mathrm{UB}$ and $\mathrm{NO}_{3-}$ in TR. In the case of Biomass Burning, while the relative contributions of all its key tracers (OC, $\mathrm{EC}$ and $\mathrm{K}^{+}$) are identical in the two profiles, the contributions of the remaining components are quite variable, but always very small, in comparison to the total mass of the profiles. It should be mentioned here that when two source profiles are compared, the comparison should be focused on the main tracer$\mathrm{s} /$ markers of the source regardless of their concentration in the factor. The wide range of biomass burning types (i.e. type of biofuel, combustion regime/appliances, open fire such as in forest fire events or residential biomass burning) may account for this variability in the "tracer" species found in the profiles. For instance, the presence of As, mainly in the UB profile, may be attributed to the burning of treated wood, since As is used as preservative in treated wood (Van Grieken and Markowicz, 2002). Indeed, burning of treated wood and/or waste for residential heating was observed in Athens during that period, in the middle of the Greek financial crisis (Amato et al., 2016). In the chemical profiles of the source of Sulfates and Organics, the contributions of $\mathrm{OC}, \mathrm{NH}^{+}$and $\mathrm{SO}_{4-}{ }^{2}$ are almost identical. The presence of $\mathrm{K}^{+}$in the profiles of both sites, indicates some mixing of this factor with biomass burning. This might be attributed to the fact that $\mathrm{K}$ originating from biomass burning is emitted as $\mathrm{KCl}$ (young smoke) and it is then transformed to $\mathrm{K}_{2} \mathrm{SO}_{4}$ (aged smoke), which is a more stable form (Niemi et al., 2004). As it is reported in previous studies, young BB is primary while aged BB is a secondary source and in some cases appear as two separate source categories (Perrone et al., 2018). It is considered that because $\mathrm{K}$ is in the form of $\mathrm{K}_{2} \mathrm{SO}_{4}$ the model apportions a part of it to the factor that represents sulfates.

The Exhaust Emissions profiles displayed moderate Pearson correlation between the two sites. The main tracers at both sites were, as expected, EC and OC, but the OC/EC ratio was much higher in the UB site. This difference may be attributed to the chemical composition of fresh and aged exhaust emissions (e.g. production of secondary organic aerosol from VOCs in the UB site) but also to a higher traffic density of diesel vehicles at the TR site (such as taxis, buses and commercial LDVs); diesel exhaust emissions display OC/EC ratios close to 1 (Argyropoulos et al., 2012). The profiles also display different contributions of "minor" tracers. Specifically, the UB Exhaust emissions profiles appears to be affected by non-Exhaust emissions because of the much higher contributions of soil related and anthropogenic elements that are mainly emitted from this source ( $\mathrm{Mg}, \mathrm{Al}, \mathrm{Si}, \mathrm{Ca}, \mathrm{Ti}, \mathrm{Fe}, \mathrm{Cu}$ and $\mathrm{Zn})$. The traffic related sources have a much higher contribution to PM in the TR site and are mainly transported from TR to UB site. Since both sources (Exhaust and non-Exhaust emissions) are transported at the same time to the UB site, the model might misinterpret this correlation and produce slightly

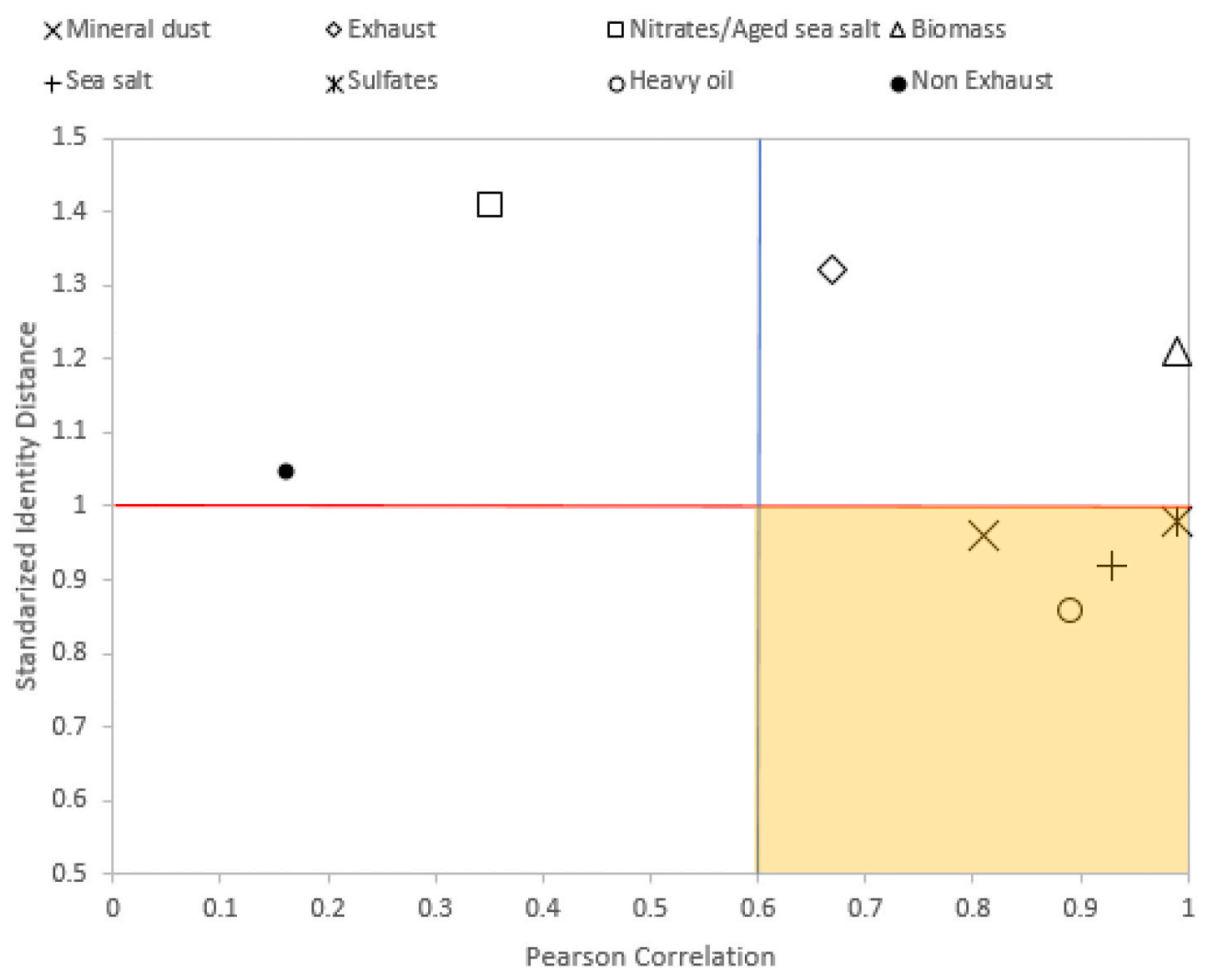

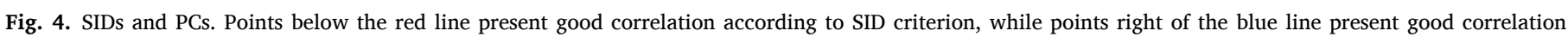

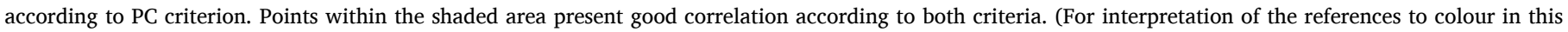
figure legend, the reader is referred to the Web version of this article.) 
mixed factors. Sources such as combustion sources that produce fine aerosols, are expected to have source profiles less affected due to transportation in small distances because fine aerosols have higher residence time.

The sources that displayed low correlation are Nitrates/Aged Sea Salt and non-Exhaust Emissions. Nitrates and Aged Sea Salt are the only two sources that, even though were identified by the same key tracer (nitrates), they were classified as different sources. The fact that the statistical factors confirm the discrete chemical nature of the profiles, validates their original classification as different sources. At both sites, nitrates were major contributors to the source profiles. What distinguishes the two profiles and leads to the assignment of different source types to them, is the significant contribution of $\mathrm{Na}^{+}$in the UB profile and of $\mathrm{NH}_{4}^{+}$in the TR profile. The presence of $\mathrm{Na}^{+}$in the UB profile indicates the production of $\mathrm{NaNO}_{3}$, due to the interaction of sea salt aerosol with anthropogenic gaseous precursors (NOx) (Eleftheriadis et al., 2014). The nitrates profile found in TR, on the other hand, includes mainly nitrate, ammonium, OC and sulphate. The secondary sulphate present in this factor seems to be related rather to local than regional origin, as demonstrated by the presence of nitrate as well. Nitrate is known to be formed faster than sulphate, and is thus more often related to local rather than regional sources. The presence of organics in the Nitrates profile further support the secondary nature of this source. The identification of these two rather similar, but not identical profiles, highlights the different processes that may take place in centrally located and background sites. The TR site is more impacted by fresh emissions from the city sources and thus tends to display more "clear" source profiles. The UB site, on the other hand, receives a mixture of pollutants emitted from both anthropogenic and natural sources and transported to this receptor site; the interaction of these pollutants while traveling to the UB site is reflected by the presence of mixed source profiles (such as the case of secondary nitrate coupled with sea salt aerosol).

The Non-Exhaust profiles display low Pearson correlation and the contributions to PM are also very different. It is well established that the chemical trail of non-exhaust vehicle emissions (or road dust) is composed of soil related elements and anthropogenic elements that originate from the abrasion of different parts of the vehicles such as the tires, brakes and the body (Amato et al., 2009; Thorpe and Harrison, 2008). The profiles suggest that the contribution of the soil related elements ( $\mathrm{Mg}, \mathrm{Al}, \mathrm{Si}, \mathrm{Ca}, \mathrm{Ti}, \mathrm{Fe}$ ) is higher in TR site, while the contribution of the anthropogenic elements is higher in the UB (Ni, Zn). This fact might be explained if we take into account the proximity of the sampling site to the source. In UB site the resuspension of the road dust is taking place further away from the sampling point, which means that the chemical trail of the non-exhaust emissions is more enriched with fine elements and less with coarse ones. Elements that originate from natural sources such as soil are mainly in the coarse fraction (Karanasiou et al., 2007), and they have lower residence time in the atmosphere. In the traffic site, on the other hand, the resuspension is taking place in close proximity to the sampling point and thus the enrichment of the factor with coarse elements of natural origin is higher. Another significant difference observed between the UB and TR profiles is the absence of OC from the UB non-exhaust profile. This may be due to its low contribution to this factor, in comparison to other factors, such as Vehicle Exhaust and Sulfates \& Organics. It should be noted that most of OC was apportioned to these two factors/sources, while Sulfates \& Organics also displayed the highest contribution to PM mass at the UB site.

An additional statistical indicator was utilized in order to quantify the "similarity" between the source profiles. As it was stated before, even though Pearson correlation is a well-established and widely used statistical tool, it has some weaknesses (e.g. it is mostly influenced by the most abundant species). The SID was used for that reason, a tool that has been showcased that it can quantify well the similarity of source profiles and contributions in source apportionment studies (Belis et al., 2015a,b; Pernigotti et al., 2016). The results are presented in Table 2. SID values that are above 1 represent source profiles with low/no correlation.

Out of the six sources that presented high PC coefficients (Fig. 4), four were correlated according to SID as well. The source profile that was not correlated in this case was the one that corresponds to Biomass Burning. According to PC the Biomass Burning profiles from the two sites were highly correlated (0.99) while the SID was found to be 1.21. The reason for this discrepancy is related with the level of influence the marginal species have on the PC test. SID as equation (2) suggests, is equally affected by all the species $\mathrm{j}$ in a factor, regardless of their relative mass in the source profile, while in PC, species with high relative abundance affect disproportionally the results. In Fig. 4 (left) the correlation of relative contributions for all species found in the Biomass Burning profiles is presented. It can be seen that the species with high relative contributions, which in this case are $\mathrm{EC}$ and OC, are within the acceptability limits and in the case of EC almost on the identity line.

In Fig. 5 (right), EC and OC have been removed from the graphical representation and it becomes apparent that almost all the other species that are present in the factor apart from EC and OC are outside the acceptability thresholds, leading to a SID value over 1 . Since the species that are considered tracers for the Biomass Burning source (EC, OC, $\mathrm{K}^{+}$) are within the acceptability limits, both the UB and TR profiles may indeed be classified to this source. But SID reveals that some nonnegligible differences exist in the two profiles that are associated with tracers with low relative masses. The TR profile contains elements that are related with traffic emissions, which might indicate that because of
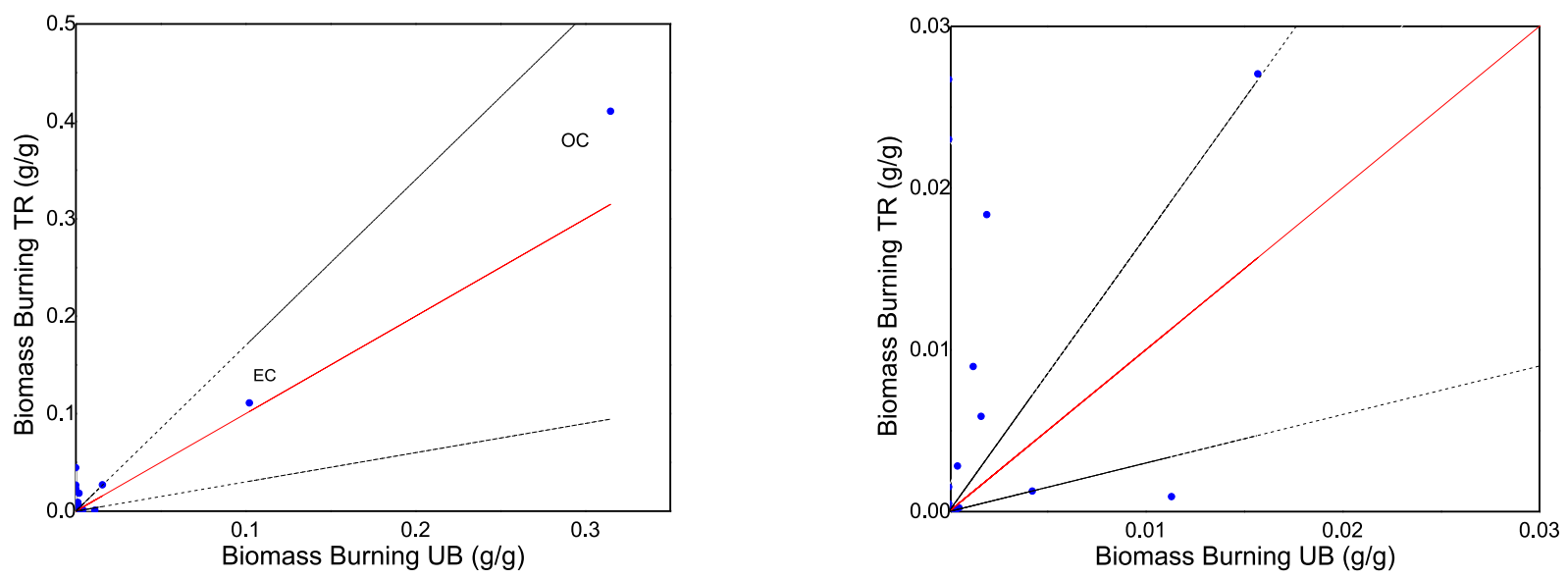

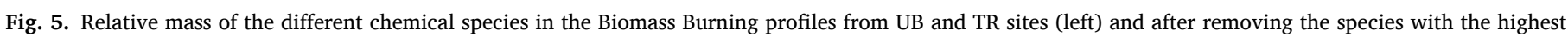

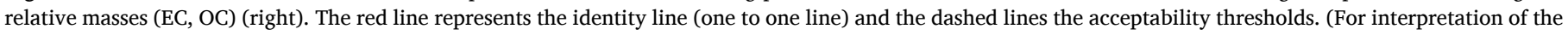
references to colour in this figure legend, the reader is referred to the Web version of this article.) 


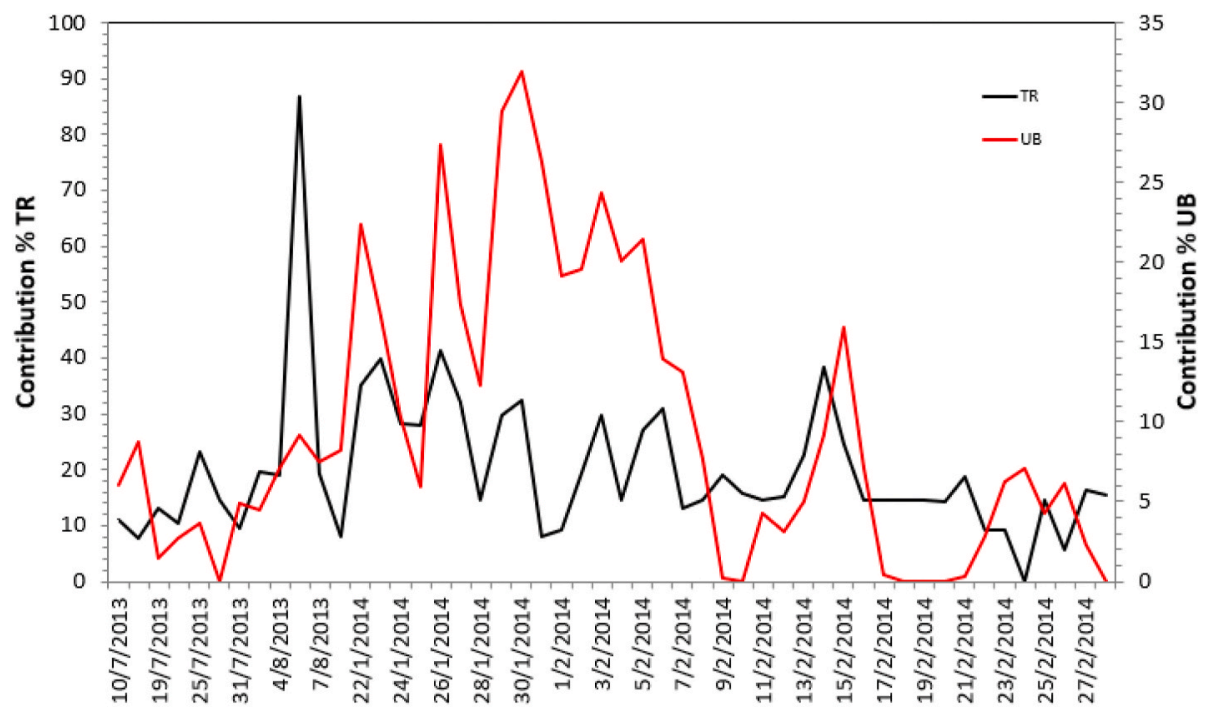

Fig. 6. $24 \mathrm{~h}$ contribution of Biomass Burning at the two sites (left axis TR, right axis UB).

Table 3

Pearson correlation between the $24 \mathrm{~h}$ source contributions (time series) for the two sites and Pearson correlation only in days with wind speed (ws) $>2 \mathrm{~m} / \mathrm{s}$.

\begin{tabular}{|c|c|c|c|c|c|c|c|c|}
\hline & $\begin{array}{l}\text { non Exhaust } \\
\text { Traffic }\end{array}$ & $\begin{array}{l}\text { Mineral } \\
\text { Dust }\end{array}$ & $\begin{array}{l}\text { Vehicle } \\
\text { Exhaust }\end{array}$ & $\begin{array}{l}\text { Aged Sea Salt/ } \\
\text { Nitrates }\end{array}$ & $\begin{array}{l}\text { Biomass } \\
\text { Burning }\end{array}$ & $\begin{array}{l}\text { Fresh Sea } \\
\text { Salt }\end{array}$ & $\begin{array}{l}\text { Secondary Sulfates \& } \\
\text { Organics }\end{array}$ & $\begin{array}{l}\text { Heavy Oil } \\
\text { Combustion }\end{array}$ \\
\hline PM10 & 0.51 & 0.87 & -0.14 & -0.02 & -0.12 & 0.87 & 0.82 & 0.16 \\
\hline PM2.5 & 0.33 & 0.41 & -0.40 & -0.18 & 0.05 & 0.70 & 0.81 & 0.09 \\
\hline $\begin{array}{l}\text { PM10 ws }>2 \\
\text { m/s }\end{array}$ & 0.47 & 0.82 & -0.10 & 0.38 & -0.18 & 0.89 & 0.82 & 0.53 \\
\hline $\begin{array}{l}\mathrm{PM} 2.5 \text { ws }>2 \\
\mathrm{~m} / \mathrm{s}\end{array}$ & 0.03 & 0.31 & -0.38 & 0.05 & -0.02 & 0.78 & 0.83 & 0.16 \\
\hline
\end{tabular}

the very prominent contribution of traffic in this site, there is a level of mixing with sources that have similar tracers. The minor tracers in a profile might not be so important for the assignment of a profile to a source category but might provide information regarding different processes/conditions that impact the various sites as well as the statistical inaccuracies that may exist in the modeling process. For that reason, SID is considered as a more appropriate test to evaluate the similarity of two profiles, as it is more sensitive to the variation of all species on the factor regardless of their relative weight. This is particularly important when the source markers are species with low abundance such as trace elements or specific organic compounds (e.g. PAHs).

Overall, both tests indicated the robustness of the model results, since sources that are not expected to have spatial variation with respect to their chemical profiles, were well correlated based on both tests. SID test is more sensitive to the differences of tracers with low relative masses in the factors. Regarding the source profiles that displayed significant spatial variability, it would be useful to characterize them based not only on the type of source but also on the type of receptor site for which they are used. For example, Traffic or non-Exhaust might not be enough to fully describe the source, but a characterization such as Urban Background Traffic might be more appropriate. It should be noted that, when examining a source profile and respective contribution to PM, the other sources should be also taken into account, since the model provides a solution including all contributions that are summed to $100 \%$, meaning that whatever affects one factor directly affects the others.

All sources have higher mass contributions in TR site, with the highest difference observed for the two traffic related sources (Exhaust and non-Exhaust Emissions) and Biomass Burning. Biomass burning contribution in TR site is highly affected by a very high contribution due to a forest fire on the outskirts of Athens on the summer of 2013. All these sources are referring to combustion processes and all three have dissimilar chemical profiles according to the SID test. The high difference between the two sites for the traffic related sources was expected and is attributed to the relative proximity of the sampling point to the source as well as the higher traffic density in the city center in comparison to the urban background area where the UB site is located. Regarding Biomass Burning, TR displays higher contributions even during the warm season of the year (Fig. 6). The winter-time difference may be related to the higher population density around the TR site, which impacts the contribution of residential biomass burning. On the other hand, the increased summer-time Biomass Burning contributions cannot be attributed to local biomass burning inside the urban agglomeration. This finding rather suggests that TR is more affected than UB by the long-range transport of biomass burning aerosol from rural areas around Athens or further away or/and that there is a level of mixing of Biomass with other combustion sources. It is known from other studies that it is common for sources that have a large number of common tracers (such as different type of combustion processes) to display a level of mixing (Manousakas et al., 2015), which might be reflected to the source contributions.

Natural sources (Sea Salt and Mineral Dust) display lower differences regarding the mass contributions compared to anthropogenic sources; this is expected due to the non-local character of these sources inside the urban agglomeration. It should be noted that Sulfates displayed the lowest spatial variability (almost identical mass contributions at the two sites). Sulfates have been found to have similar concentrations in several areas in the Mediterranean region (Argyropoulos et al., 2012), highlighting the regional character of these secondary aerosol species.

To evaluate the correlation of the $24 \mathrm{~h}$ source contribution time series at the two sites, the Pearson correlation coefficients were calculated. The results are presented in Table 3.

High correlation coefficients were obtained in the case of Mineral Dust (only $\mathrm{PM}_{10}$ ), Sea Salt and Sulfates and Organics, all three sources displaying also the lowest spatial variability with respect to contribution 
levels. The $24 \mathrm{~h}$ contributions of the remaining sources at the two sites do not appear to be correlated, with the exception of non-Exhaust emissions that display moderate correlation for $\mathrm{PM}_{10}$. The fact that even though the source profiles of non-exhaust emissions from the two sites are not correlated but the contributions in $\mathrm{PM}_{10}$ present a moderate correlation may indicate the effect that the distance from the source to the receptor has on this source.

To investigate if wind speed can affect the mixing levels in Athens Metropolitan area and thus increase the correlation between the contributions of the sources in the two sites, the Pearson correlations were calculated only for the days that the wind speed was higher than $2 \mathrm{~m} / \mathrm{s}$.

The only source that appears to be affected by the wind speed is Heavy Oil Combustion which displays higher correlation in this case. Heavy Oil combustion displayed similar source profiles at the two sites possibly indicating a regional character for this source. The correlation observed between source contributions during high wind speeds $(>2 \mathrm{~m} /$ s) further supports that the origin of this source is outside the urban agglomeration (i.e. industrial and shipping emissions).

\subsection{DeltaSA tool}

The Non-Exhaust is coherent with traffic and road dust according to SID but not Pearson Distance. The analysis confirms the allocation for TR site. For UB site according to the tool the profile is coherent with steel plant, fertilizer, fly ash, road dust and power plant according to SID but not Pearson Distance. The analysis confirms the allocation but the profile seems to have some noise which is attributed to the distance of the source to the receptor site.

Mineral dust is coherent with volcanic soil, soil, road, construction and fly ash according to both SID and PD for both sites. The allocation is confirmed.

Exhaust profile is coherent with exhaust, biomass burning, wood burning and diesel according to both SID and PD for both sites. The closest is exhaust so the allocation is confirmed. However, there is not clear distinction from biomass burning, likely due to the lack of more specific markers (e.g. levoglucosan).

Heavy oil is coherent with fuel oil, steel plant and powerplant according to SID but not PD for UB site. Fuel oil is the closest, the allocation is confirmed. For TR site is coherent with exhaust according to both SID and PD. This indicates, as discussed earlier, that the overwhelming contribution of traffic in the TR site leads to mixed profiles with other combustion sources.

Biomass is coherent with exhaust, biomass burning, wood burning, traffic and diesel according to both SID and PD for TR site. The allocation is confirmed, however, also the closeness to the exhaust profile is evident also in the results of DeltaSA tool. Biomass in UB site is coherent with power plant, ceramic, industry, fertilizer, waste, and coal according to SID. As discussed in a previous section, the fact that the Biomass profile of the UB site presents similarity with waste incineration profile more than that of clean biomass burning is attributed to the fact that due to the economic crisis in Greece, people were burning treated wood for domestic heating releasing toxic metals in the atmosphere ( $\mathrm{As}, \mathrm{Pb}, \mathrm{Cd})$.

Sea Salt is coherent with marine salt for both SID and PD for both sites. Allocation confirmed. All other sources (Nitrates, Sulfates and Aged Sea Salt) are secondary sources and therefore not suitable to be tested with this method.

\section{Conclusions}

The aim of the study is to provide a comparison between the sources of two sites inside an urban agglomeration. One urban background site (UB) and one traffic site (TR). The comparison is not focused in the contributions of the sources, but on more qualitative characteristics of the source profiles. To quantify the differences of the source profiles, two statistical indicators were used, Pearson correlation (PC) and Standarized Identity Distance (SID).
According to PC coefficients five out of the eight source profiles present high correlation (Mineral Dust, Biomass Burning, Sea Salt, Sulfates and Heavy Oil Combustion), one presented moderate correlation (Exhaust) and two low/no correlation (non-Exhaust, Nitrates/Aged Sea Salt). The source profiles that appear to be more correlated are those of sources that are not expected to have high spatial variability because there are either natural/secondary or are emitted outside the urban agglomeration and are transported to both sites.

The results according to SID are similar to Pearson with the exception of Biomass Burning which according to SID has dissimilar source profiles at the two sites. This disagreement between the two tests is explained by the fact that SID takes all the species equally into account and is not only affected by a few number of species with very high concentrations.

Both tools have been proven to be effective for the comparison of source profiles, and both can be useful depending on the situation. SID is sensitive to the differences that result from all species in the factor, while PC is sensitive only to the species with high contributions. If the analyst bases the identification of the factor only in the "main tracers" (species with high concentrations in the factors), then PC is an effective tool. The problem with that approach is that what is some times considered as "noise" (species with low concentration) in the factor profiles, is not always an artifact of the modeling process, and it often provide information about real differences in the factors. What is suggested here, is the complementary use of both tools, and if an agreement is not achieved (as it was the case for biomass burning in the current study), then the user should carefully examine what species cause this disagreement, and how important are to the factor identification. If the criteria (SID $<1$ and PC $>0.6$ ) from both tools are met at the same time, then it can be safely concluded that the profiles are very similar or identical.

As far as the comparison between the contributions is concerned, all sources have higher mass contribution in TR site. The sources that have the highest difference regarding their mass contributions are the two traffic related sources (Exhaust and non-Exhaust Emissions) and Biomass Burning. To evaluate the correlation of the $24 \mathrm{~h}$ source contribution time series of the sources, the Pearson correlations were calculated. The natural sources (Mineral Dust, Sea Salt and Sulfates and Organics) present high correlation in both PM fractions except Mineral Dust that presents low correlation for PM2.5. Pearson correlations for the $24 \mathrm{~h}$ contributions only for the days with wind speed higher than 2 $\mathrm{m} / \mathrm{s}$, revealed that wind speed does not affect the relationship between the sources at the two sites with the exception of Heavy Oil Combustion.

This work is, to the best of our knowledge, the first time a quantitative comparison of the source profiles is carried out for sites inside the same urban agglomeration using statistical indicators. Since in many cases researchers combine datasets from different sites in order to have enough data to perform source apportionment analysis, it is very important to have information regarding the differences that exist along the chemical trails (plumes) of the sources, when the samples are collected on sites located close to each other but with different characteristics.

The fact that most of the profiles are so similar even though the runs are different for each site is an indication of the robustness of the model results. The differences in the chemical profiles of sources that have spatial variability suggest that the characterization of source profiles should refer also to the area of the study and not only to the type of source to which it was attributed. For example, Traffic or non-Exhaust might not be enough to fully describe the source, and a characterization such as Urban Background Traffic might be more appropriate. In any case, regardless of the type or the place of a source apportionment study, it is necessary to examine the model solution as a whole and not focus on its different parts, as the models always provide contributions that are summed to $100 \%$, meaning that whatever happens to one factor directly affects the others. 


\section{Credit author statement}

M. Manousakas: Conceptualization, Methodology, Formal analysis, Writing - Original Draft, Writing - Review \& Editing, E. Diapouli: Conceptualization, Formal analysis, Writing - Review \& Editing, C. A. Belis: Methodology, Software, Writing - Review \& Editing, V. Vasilatou: Investigation, M. Gini: Investigation, Visualization, F. Lucarelli: Writing - Review \& Editing, X. Querol: Writing - Review \& Editing, Funding acquisition, K. Eleftheriadis: Conceptualization, Writing Review \& Editing, Funding acquisition, Supervision

\section{Declaration of competing interest}

The authors declare that they have no known competing financial interests or personal relationships that could have appeared to influence the work reported in this paper.

\section{Acknowledgments}

The study was supported by "CALIBRA/EYIE" (MIS 5002799) and "PANhellenic infrastructure for Atmospheric Composition and climatE change" (MIS 5021516) implemented under the Action "Reinforcement of the Research and Innovation Infrastructure", funded by the Operational Programme "Competitiveness, Entrepreneurship and Innovation" (NSRF 2014-2020) and co-financed by Greece and the European Union (European Regional Development Fund). Collection and chemical analysis of samples were supported by LIFE + AIRUSE EU project (ENV/ ES/584). Partial support was also received by H2020 ERAPLANET/ SMURBS ERANET GA No 689443.

\section{Appendix A. Supplementary data}

Supplementary data to this article can be found online at https://doi. org/10.1016/j.envres.2020.110257.

\section{References}

Amato, F., Pandolfi, M., Viana, M., Querol, X., Alastuey, A., Moreno, T., 2009. Spatial and chemical patterns of PM10 in road dust deposited in urban environment. Atmos. Environ. 43, 1650-1659. https://doi.org/10.1016/j.atmosenv.2008.12.009.

Amato, F., Alastuey, A., Karanasiou, A., Lucarelli, F., Nava, S., Calzolai, G., Severi, M., Becagli, S., Gianelle, V.L., Colombi, C., Alves, C., Custódio, D., Nunes, T., Cerqueira, M., Pio, C., Eleftheriadis, K., Diapouli, E., Reche, C., Minguillón, C., Manousakas, M., Maggos, T., Vratolis, S., Harrison, R.M., Querol, X., 2016. AIRUSELIFE + : a harmonized PM speciation and source apportionment in five southern European cities. Atmos. Chem. Phys. 16, 3289-3309. https://doi.org/10.5194/acp16-3289-2016.

Argyropoulos, G., Manoli, E., Kouras, A., Samara, C., 2012. Concentrations and source apportionment of PM10 and associated major and trace elements in the Rhodes Island, Greece. Sci. Total Environ. 432, 12-22. https://doi.org/10.1016/j. scitotenv.2012.05.076.

Belis, C. a, Larsen, B.R., Amato, F., Haddad, I. El, Favez, O., Harrison, R.M., Hopke, P.K., Nava, S., Paatero, P., Prévôt, A., Quass, U., Vecchi, R., Viana, M., 2014. Air Pollution Source Apportionment with Receptor Models. Europena Union. https://doi.org/ $10.2788 / 9307$.

Belis, C.A., Karagulian, F., Amato, F., Almeida, M., Artaxo, P., Beddows, D.C.S., Bernardoni, V., Bove, M.C., Carbone, S., Cesari, D., Contini, D., Cuccia, E., Diapouli, E., Eleftheriadis, K., Favez, O., El Haddad, I., Harrison, R.M., Hellebust, S., Hovorka, J., Jang, E., Jorquera, H., Kammermeier, T., Karl, M., Lucarelli, F., Mooibroek, D., Nava, S., Nøjgaard, J.K., Paatero, P., Pandolfi, M., Perrone, M.G., Petit, J.E., Pietrodangelo, A., Pokorná, P., Prati, P., Prevot, A.S.H., Quass, U., Querol, X., Saraga, D., Sciare, J., Sfetsos, A., Valli, G., Vecchi, R., Vestenius, M., Yubero, E., Hopke, P.K., 2015a. A new methodology to assess the performance and uncertainty of source apportionment models II: the results of two European intercomparison exercises. Atmos. Environ. 123, 240-250. https://doi.org/10.1016/ j.atmosenv.2015.10.068.

Belis, C.A., Karagulian, F., Larsen, B.R., Hopke, P.K., 2013. Critical review and metaanalysis of ambient particulate matter source apportionment using receptor models in Europe. Atmos. Environ. 69, 94-108. https://doi.org/10.1016/j. atmosenv.2012.11.009.

Belis, C.A., Pernigotti, D., Karagulian, F., Pirovano, G., Larsen, B.R., Gerboles, M., Hopke, P.K., 2015b. A new methodology to assess the performance and uncertainty of source apportionment models in intercomparison exercises. Atmos. Environ. 119, 35-44. https://doi.org/10.1016/j.atmosenv.2015.08.002.
Belis, C.A., Pernigotti, D., Pirovano, G., Favez, O., Jaffrezo, J.L., Kuenen, J., Denier van Der Gon, H., Reizer, M., Riffault, V., Alleman, L.Y., Almeida, M., Amato, F., Angyal, A., Argyropoulos, G., Bande, S., Beslic, I., Besombes, J.L., Bove, M.C., Brotto, P., Calori, G., Cesari, D., Colombi, C., Contini, D., De Gennaro, G., Di Gilio, A., Diapouli, E., El Haddad, I., Elbern, H., Eleftheriadis, K., Ferreira, J., Vivanco, M.G., Gilardoni, S., Golly, B., Hellebust, S., Hopke, P.K., Izadmanesh, Y., Jorquera, H., Krajsek, K., Kranenburg, R., Lazzeri, P., Lenartz, F., Lucarelli, F., Maciejewska, K., Manders, A., Manousakas, M., Masiol, M., Mircea, M., Mooibroek, D., Nava, S., Oliveira, D., Paglione, M., Pandolfi, M., Perrone, M., Petralia, E., Pietrodangelo, A., Pillon, S., Pokorna, P., Prati, P., Salameh, D., Samara, C., Samek, L., Saraga, D., Sauvage, S., Schaap, M., Scotto, F., Sega, K., Siour, G., Tauler, R., Valli, G., Vecchi, R., Venturini, E., Vestenius, M., Waked, A., Yubero, E., 2020. Evaluation of receptor and chemical transport models for PM10 source apportionment. Atmos. Environ. X 5, 100053. https://doi.org/10.1016/j. aeaoa.2019.100053.

Calzolai, G., Nava, S., Lucarelli, F., Chiari, M., Giannoni, M., Becagli, S., Traversi, R., Marconi, M., 2015. Characterization of PM 10 sources in the central Mediterranean. Atmos. Chem. Phys. 15, 13939-13955. https://doi.org/10.5194/acp-15-139392015.

Cesari, Daniela, Donateo, A., Conte, M., Contini, D., 2016a. Inter-comparison of source apportionment of PM10using PMF and CMB in three sites nearby an industrial area in central Italy. Atmos. Res. 182, 282-293. https://doi.org/10.1016/j. atmosres.2016.08.003.

Cesari, D., Donateo, A., Conte, M., Merico, E., Giangreco, A., Giangreco, F., Contini, D., 2016b. An inter-comparison of PM2.5 at urban and urban background sites: chemical characterization and source apportionment. Atmos. Res. 174-175, 106-119. https://doi.org/10.1016/j.atmosres.2016.02.004.

Diapouli, E., Manousakas, M., Vratolis, S., Vasilatou, V., Maggos, T., Saraga, D., Grigoratos, T., Argyropoulos, G., Voutsa, D., Samara, C., Eleftheriadis, K., 2017a. Evolution of air pollution source contributions over one decade, derived by PM 10 and PM 2.5 source apportionment in two metropolitan urban areas in Greece. Atmos. Environ. https://doi.org/10.1016/j.atmosenv.2017.06.016.

Diapouli, E., Manousakas, M.I., Vratolis, S., Vasilatou, V., Pateraki, S., Bairachtari, K.A., Querol, X., Amato, F., Alastuey, A., Karanasiou, A.A., Lucarelli, F., Nava, S., Calzolai, G., Gianelle, V.L., Colombi, C., Alves, C., Custódio, D., Pio, C., Spyrou, C., Kallos, G.B., Eleftheriadis, K., 2017b. AIRUSE-LIFE +: estimation of natural source contributions to urban ambient air PM10 and PM2.5 concentrations in Southern Europe - implications to compliance with limit values. Atmos. Chem. Phys. 17, 3673-3685. https://doi.org/10.5194/acp-2016-781.

Diapouli, E., Manousakas, M.I., Vratolis, S., Vasilatou, V., Pateraki, S., Bairachtari, K.A., Querol, X., Amato, F., Alastuey, A., Karanasiou, A.A., Lucarelli, F., Nava, S., Calzolai, G., Gianelle, V.L., Colombi, C., Alves, C., Custódio, D., Pio, C., Spyrou, C., Kallos, G.B., Eleftheriadis, K., 2016. AIRUSE-LIFE +: estimation of natural source contributions to urban ambient air PM10 and PM2.5 concentrations in Southern Europe. Implications to compliance with limit values. Atmos. Chem. Phys. Discuss. 1-25. https://doi.org/10.5194/acp-2016-781.

Donaldson, K., Brown, D.M., Mitchell, C., Dineva, M., Beswick, P.H., Gilmour, P., MacNee, W., 1997. Free radical activity of PM10: iron-mediated generation of hydroxyl radicals. Environ. Health Perspect. 105, 1285-1289. Suppl.

Eleftheriadis, K., Ochsenkuhn, K.M., Lymperopoulou, T., Karanasiou, A., Razos, P., Ochsenkuhn-Petropoulou, M., 2014. Influence of local and regional sources on the observed spatial and temporal variability of size resolved atmospheric aerosol mass concentrations and water-soluble species in the Athens metropolitan area. Atmos. Environ. 97, 252-261. https://doi.org/10.1016/j.atmosenv.2014.08.013.

Gunchin, G., Manousakas, M., Osan, J., Karydas, A.G., Eleftheriadis, K., Lodoysamba, S., Shagjjamba, D., Migliori, A., Padilla-Alvarez, R., Streli, C., Darby, I.G., 2019. Threeyear long source apportionment study of airborne particles in Ulaanbaatar using Xray fluorescence and Positive Matrix Factorization. Aerosol Air Qual. Res. 5, 1056-1067. https://doi.org/10.4209/aaqr.2018.09.0351.

Kalogridis, A.-C., Vratolis, S., Liakakou, E., Gerasopoulos, E., Mihalopoulos, N., Eleftheriadis, K., 2017. Assessment of wood burning versus fossil fuel contribution to wintertime black carbon and carbon monoxide concentrations in Athens, Greece. Atmos. Chem. Phys. Discuss. 1-20. https://doi.org/10.5194/acp-2017-854.

Karanasiou, A., Sitaras, I., Siskos, P., Eleftheriadis, K., 2007. Size distribution and sources of trace metals and n-alkanes in the Athens urban aerosol during summer. Atmos. Environ. 41, 2368-2381. https://doi.org/10.1016/j.atmosenv.2006.11.006.

Katsouyanni, K., 2003. Ambient air pollution and health. Br. Med. Bull. 68, 143-156. https://doi.org/10.1093/bmb/ldg028.

Kim, E., Larson, T.V., Hopke, P.K., Slaughter, C., Sheppard, L.E., Claiborn, C., 2003. Source identification of PM2.5 in an arid Northwest U.S. City by positive matrix factorization. Atmos. Res. 66, 291-305. https://doi.org/10.1016/S0169-8095(03) 00025-5.

Kim Oanh, N.T., Pongkiatkul, P., Upadhyay, N., Hopke, P.P., 2009. Designing ambient particulate matter monitoring program for source apportionment study by receptor modeling. Atmos. Environ. 43, 3334-3344. https://doi.org/10.1016/j. atmosenv.2009.04.016.

Lee, S., Liu, W., Wang, Y., Russell, A.G., Edgerton, E.S., 2008. Source apportionment of PM2.5: comparing PMF and CMB results for four ambient monitoring sites in the southeastern United States. Atmos. Environ. 42, 4126-4137. https://doi.org/ 10.1016/j.atmosenv.2008.01.025.

Lucarelli, F., Calzolai, G., Chiari, M., Giannoni, M., Mochi, D., Nava, S., Carraresi, L., 2014. The upgraded external-beam PIXE/PIGE set-up at LABEC for very fast measurements on aerosol samples. Nucl. Instrum. Methods Phys. Res. Sect. B Beam Interact. Mater. Atoms 318, 55-59. https://doi.org/10.1016/j.nimb.2013.05.099.

Lucarelli, F., Chiari, M., Calzolai, G., Giannoni, M., Nava, S., Udisti, R., Severi, M., Querol, X., Amato, F., Alves, C., Eleftheriadis, K., 2015. The role of PIXE in the 
AIRUSE project "testing and development of air quality mitigation measures in Southern Europe. Nucl. Instrum. Methods Phys. Res. Sect. B Beam Interact. Mater. Atoms 363, 92-98. https://doi.org/10.1016/j.nimb.2015.08.023.

Manousakas, M., Diapouli, E., Papaefthymiou, H., Migliori, a., Karydas, a.G., PadillaAlvarez, R., Bogovac, M., Kaiser, R.B., Jaksic, M., Bogdanovic-Radovic, I., Eleftheriadis, K., 2015. Source apportionment by PMF on elemental concentrations obtained by PIXE analysis of PM10 samples collected at the vicinity of lignite power plants and mines in Megalopolis, Greece. Nucl. Instrum. Methods Phys. Res. Sect. B Beam Interact. Mater. Atoms 349, 114-124. https://doi.org/10.1016/j. nimb.2015.02.037.

Manousakas, M., Papaefthymiou, H., Diapouli, E., Migliori, A., Karydas, A.G., Bogdanovic-Radovic, I., Eleftheriadis, K., 2017. Assessment of PM2.5 sources and their corresponding level of uncertainty in a coastal urban area using EPA PMF 5.0 enhanced diagnostics. Sci. Total Environ. 574, 155-164. https://doi.org/10.1016/j. scitotenv.2016.09.047.

Nava, S., Becagli, S., Calzolai, G., Chiari, M., Lucarelli, F., Prati, P., Traversi, R., Udisti, R., Valli, G., Vecchi, R., 2012. Saharan dust impact in central Italy: an overview on three years elemental data records. Atmos. Environ. 60, 444-452. https://doi.org/10.1016/j.atmosenv.2012.06.064.

Niemi, J.V., Tervahattu, H., Vehkamäki, H., Kulmala, M., Koskentalo, T., Sillanpää, M., Rantamäki, M., 2004. Characterization and source identification of a fine particle episode in Finland. Atmos. Environ. 38, 5003-5012. https://doi.org/10.1016/j. atmosenv.2004.06.023.

Norris, G., Brown, S., 2014. EPA Positive Matrix Factorization (PMF) 5.0 Fundamentals and User Guide. EPA PMF 5.0 Man.

Ostro, B., Tobias, A., Karanasiou, A., Samoli, E., Querol, X., Rodopoulou, S., Basagaña, X., Eleftheriadis, K., Diapouli, E., Vratolis, S., Jacquemin, B., Katsouyanni, K., Sunyer, J., Forastiere, F., Stafoggia, M., 2014. The risks of acute exposure to black carbon in Southern Europe: results from the MED-PARTICLES project. Occup. Environ. Med. 1-7. https://doi.org/10.1136/oemed-2014-102184.

Pandolfi, M., Gonzalez-Castanedo, Y., Alastuey, A., de la Rosa, J.D., Mantilla, E., de la Campa, a S., Querol, X., Pey, J., Amato, F., Moreno, T., 2011. Source apportionment of PM(10) and PM(2.5) at multiple sites in the strait of Gibraltar by PMF: impact of shipping emissions. Environ. Sci. Pollut. Res. Int. 18, 260-269. https://doi.org/ 10.1007/s11356-010-0373-4.

Pateraki, S., Manousakas, M., Bairachtari, K., Kantarelou, V., Eleftheriadis, K., Vasilakos, C., Assimakopoulos, V.D., Maggos, T., 2019. The traffic signature on the vertical PM profile: environmental and health risks within an urban roadside environment. Sci. Total Environ. 646, 448-459. https://doi.org/10.1016/j. scitotenv.2018.07.289.

Pernigotti, D., Belis, C.A., 2018. DeltaSA tool for source apportionment benchmarking, description and sensitivity analysis. Atmos. Environ. 180, 138-148. https://doi.org/ 10.1016/j.atmosenv.2018.02.046.

Pernigotti, D., Belis, C.A., Spano, L., 2016. SPECIEUROPE: the European data base for PM source profiles. Atmos. Pollut. Res. 7, 307-314. https://doi.org/10.1016/j. apr.2015.10.007.

Perrone, M.G., Vratolis, S., Georgieva, E., Török, S., Šega, K., Veleva, B., Osán, J. Bešlić, I., Kertész, Z., Pernigotti, D., Eleftheriadis, K., Belis, C.A., 2018. Sources and geographic origin of particulate matter in urban areas of the Danube macro-region: the cases of Zagreb (Croatia), Budapest (Hungary) and Sofia (Bulgaria). Sci. Total Environ. 619-620, 1515-1529. https://doi.org/10.1016/j.scitotenv.2017.11.092.

Querol, X., Alastuey, A., Rodriguez, S., Plana, F., Mantilla, E., Ruiz, C.R., 2001. Monitoring of PM10 and PM2.5 around primary particulate anthropogenic emission sources. Atmos. Environ. 35, 845-858. https://doi.org/10.1016/S1352-2310(00) 00387-3.

Sarigiannis, D.A., Handakas, E.J., Kermenidou, M., Zarkadas, I., Gotti, A., Charisiadis, P., Makris, K., Manousakas, M., Eleftheriadis, K., Karakitsios, S.P., 2017. Monitoring of air pollution levels related to Charilaos Trikoupis Bridge. Sci. Total Environ. 609, 1451-1463. https://doi.org/10.1016/j.scitotenv.2017.06.230.

Shiraiwa, M., Ammann, M., Koop, T., Pöschl, U., 2011. Gas uptake and chemical aging of semisolid organic aerosol particles. Proc. Natl. Acad. Sci. U.S.A. 108, 11003-11008. https://doi.org/10.1073/pnas.1103045108.

Van Grieken, R., Markowicz, A., 2002. Handbook of X-Ray Spectrometry, second ed. Macvel Dekker, New York. Revised and Expanded, Second.

Waked, A., Favez, O., Alleman, L.Y., Piot, C., Petit, J.E., Delaunay, T., Verlinden, E. Golly, B., Besombes, J.L., Jaffrezo, J.L., Leoz-Garziandia, E., 2014. Source apportionment of PM10 in a north-western Europe regional urban background site (Lens, France) using positive matrix factorization and including primary biogenic emissions. Atmos. Chem. Phys. 14, 3325-3346. https://doi.org/10.5194/acp-143325-2014.

Zwozdziak, A., Gini, M.I., Samek, L., Rogula-Kozlowska, W., Sowka, I., Eleftheriadis, K., 2017. Implications of the aerosol size distribution modal structure of trace and major elements on human exposure, inhaled dose and relevance to the PM2.5 and PM10 metrics in a European pollution hotspot urban area. J. Aerosol Sci. 103, 38-52. https://doi.org/10.1016/j.jaerosci.2016.10.004. 